\title{
Parallel Profiles of Inflammatory and Effector Memory T Cells in Visceral Fat and Liver of Obesity-Associated Cancer Patients
}

\author{
Melissa Conroy \\ Trinity College Dublin, Ireland \\ Karen Galvin \\ Trinity College Dublin, Ireland \\ Suzanne Doyle \\ Technological University Dublin, suzanne.doyle@tudublin.ie
}

See next page for additional authors

Follow this and additional works at: https://arrow.tudublin.ie/scschbioart

Part of the Dietetics and Clinical Nutrition Commons, and the Oncology Commons

\section{Recommended Citation}

Conroy, M.J., Galvin, K.C., Doyle, S.L. et al. Parallel Profiles of Inflammatory and Effector Memory T Cells in Visceral Fat and Liver of Obesity-Associated Cancer Patients. Inflammation 39, 1729-1736 (2016). DOI: 10.1007/s10753-016-0407-2

This Article is brought to you for free and open access by the School of Biological Sciences at ARROW@TU Dublin. It has been accepted for inclusion in Articles by an authorized administrator of ARROW@TU Dublin. For more information, please contact arrow.admin@tudublin.ie, aisling.coyne@tudublin.ie,gerard.connolly@tudublin.ie. Funder: Health Research Board, Ireland

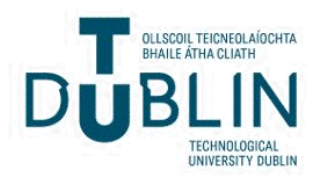




\section{Authors}

Melissa Conroy, Karen Galvin, Suzanne Doyle, Maria Kavanagh, Ann-Marie Mongan, Aoife Cannon, Gillian Moore, John Reynolds, and Joanne Lysaght 


\title{
Parallel Profiles of Inflammatory and Effector Memory $\mathbf{T}$ cells in Visceral
}

\section{Fat and Liver of Obesity-associated Cancer Patients.}

\author{
"Melissa J. Conroy $\dagger$, Karen C. Galvin $\dagger$, Suzanne L. Doyle $\nmid ¥$, Maria E. Kavanagh $\dagger$, \\ Ann-Marie Mongan $\dagger$, Aoife Cannon $\dagger$, Gillian Y. Moore $\dagger$, John V. Reynolds $\uparrow \dagger$ and \\ Joanne Lysaght $\dagger$. \\ $\dagger$ Trinity Translational Medicine Institute, Department of Surgery, Trinity College Dublin, St James’s \\ Hospital, Dublin 8, Ireland. \\ †Oesophageal Unit, St. James’s Hospital, Dublin, Ireland \\ $¥$ School of Biological Sciences, Dublin Institute of Technology, Dublin, Ireland \\ Address for correspondence: \\ Dr. Joanne Lysaght \\ Tumour Immunology Group \\ Department of Surgery \\ Trinity Translational Medicine Institute, \\ St. James's Hospital \\ Dublin 8, Ireland \\ Tel: $+353-1-8964259$ \\ E-mail: jlysaght@tcd.ie
}

\section{Acknowledgements}

The authors would like to thank all of the patients attending the Oesophageal Unit at St. James's Hospital, Dublin for their participation in this study. 


\section{Keywords}

Inflammation, obesity, cancer, $\mathrm{T}$ cells, liver, omentum 


\section{Introduction}

Obesity has reached epidemic proportions worldwide and is now estimated to contribute to approximately 3.5 million deaths every year $[1,2,3,4]$. The association between obesity and cancer is well established and may be associated with the development of $40 \%$ of certain malignancies in the US $[4,5,6]$. The expansion of adipose tissue due to obesity results in enhanced angiogenesis, increased infiltration of inflammatory macrophages and $\mathrm{T}$ cells and significantly greater release of pro-inflammatory factors including TNF- $\alpha$, IL- $1 \beta$, IL-6, IL-12 and IFN- $\gamma$, all of which contribute to a systemic state of chronic inflammation [7]. Such chronic inflammation and excessive pro-inflammatory cytokine production can result in genomic instability and the initiation of cancer. Furthermore, alterations in key lymphocyte subsets such as $\mathrm{CD}^{+}$and $\mathrm{CD} 8^{+} \mathrm{T}$ cells, NK, NKT and regulatory $\mathrm{T}$ (Treg) cells have been reported in obese cancer patients, which may negatively impact anti-tumour immune responses $[8,9,10,11,12]$.

Excess visceral adipose tissue (VAT) is considered a more important risk factor for cancer development, inflammation and dysmetabolism than subcutaneous fat. The omentum, which drains into the liver via the portal circulation, forms the largest component of the VAT compartment. We and others have previously shown that the omentum is enriched with activated pro-inflammatory $\mathrm{T}$ cells, now understood to be pivotal in both the establishment and maintenance of adipose tissue inflammation in obesity $[8,13]$. Importantly, we have also demonstrated that the omentum and liver are enriched in inflammatory cytokines and chemokines that facilitate $\mathrm{T}$ cell migration to these sites [7, 14]. Furthermore, our group reported that chemokine receptor antagonism is a potential novel treatment strategy to reduce T cell infiltration to the omentum and liver [14].

The aim of this study was to ascertain the role of $\mathrm{T}$ cells in inflammation within the omentum and liver of patients with an inflammation-driven and obesity-associated cancer, 
oesophageal adenocarcinoma (OAC), and to compare $\mathrm{T}$ cell phenotypes at these two important sites. As the incidence of OAC is increasing dramatically, paralleling that of the obesity epidemic, it is a highly relevant clinical model with which to study the underlying mechanisms and potential therapeutic targets for obesity-associated inflammation, and lessons learned may also apply to other obesity-associated malignancies. By evaluating whether the inflammatory profile of the $\mathrm{T}$ cell infiltrates in liver are similar to those in omentum, novel insights on potential targets relevant to cancer and obesity-associated liver inflammation may be uncovered. 


\section{Materials and Methods}

\section{Subjects}

Twenty four consecutive consenting patients with oesophageal adenocarcinoma, attending the Oesophageal Unit at St. James Hospital, Dublin from 2011 to 2014 were enrolled in this study. The patient cohort was similar in age and race, and 23 had received neo-adjuvant chemo-radiotherapy. The patient group included 22 males and 2 females, representative of the male predominance in oesophageal adenocarcinoma, with an average age of $63.5 \mathrm{yrs}$. The mean BMI was 25.8. Patients provided informed consent for sample acquisition and the study received ethical approval from the St James's Hospital Ethics Review Board. All cancer patients were evaluated by a dietician. Body mass index, waist circumference and anthropometric variables were measured as described previously [8]. Visceral fat area was assessed by computer tomography as previously described, with more than $160 \mathrm{~cm}^{2}$ and $80 \mathrm{~cm}^{2}$ defining visceral obesity in males and females, respectively [15].

\section{Sample Preparation}

Peripheral blood mononuclear cells (PBMC) were isolated by density centrifugation using Ficoll-Paque $^{\mathrm{TM}}$ Plus (GE Healthcare, Uppsala, Sweden). Omental samples (10 g) were digested enzymatically as previously described to obtain stromal vascular fraction (SVF) [8]. Liver samples were processed as described previously with slight modifications [16]. Briefly, liver tissue ( $1 \mathrm{~g}$ ) was digested enzymatically in a $50 \mathrm{ml}$ tube containing $25 \mathrm{ml}$ Disruption Enzyme Mix Solution (50 ml HBSS + 0.025 g Collagenase type IV $(0.05 \%)+100 \mu$ DNAse I $(10 \mathrm{mg} / \mathrm{ml})(0.002 \%)+1 \mathrm{ml} \mathrm{FCS}+1 \mathrm{ml} 30 \% \mathrm{BSA})$. Tissue was incubated for 35 minutes on a shaking incubator at $37^{\circ} \mathrm{C}$ at $180 \mathrm{RPM}$ before being passed through a $70 \mu \mathrm{m}$ polypropylene filter (Filcon; BD Bioscience, San Jose, California, USA) to discard debris. Cells were washed twice with HBSS and centrifuged at 1300 RPM for 3 minutes. The cell pellet was resuspended in $0.87 \%$ ammonium chloride solution to lyse contaminating 
erythrocytes. The remaining intrahepatic immune cells were counted and assessed for viability by trypan blue. Adipose conditioned media (ACM) was prepared as previously described, briefly omentum was minced using a scalpel, adding $10 \mathrm{ml}$ of serum-free M199 media per $5 \mathrm{~g}$ of omentum and incubating at $37^{\circ} \mathrm{C}, 5 \% \mathrm{CO}_{2}$ for 72 hours. Following 72 hours, the media was passed through a $70 \mu \mathrm{m}$ polypropylene filter to discard debris [7]. Liver conditioned media (LCM) was prepared as previously described by mincing liver using a scalpel, adding $350 \mu \mathrm{l}$ of serum-free M199 media per $0.1 \mathrm{~g}$ of liver and incubating at $37^{\circ} \mathrm{C}$, $5 \% \mathrm{CO}_{2}$ for 72 hours. Following 72 hours, the media was passed through a $70 \mu \mathrm{m}$ polypropylene to remove debris [14].

\section{Antibodies and flow cytometry}

Freshly-isolated PBMC, SVF and intrahepatic immune cells were stained with monoclonal antibodies (mAbs) specific for human surface markers (CD3, CD4, CD8, CD45RA, CD69; BD Biosciences, Oxford, UK), CD27 (eBioscience, Hatfield, UK) and CD62L (Abcam, Cambridge, UK). Gating strategy for surface markers is outlined in supplemental Figure 1A. For intracellular cytokine staining cells were stimulated with $10 \mathrm{ng} / \mathrm{ml}$ of phorbal myristate acetate and $1 \mu \mathrm{g} / \mathrm{ml}$ of ionomycin (PMA/I) for 1 hour, followed by the addition of $10 \mu \mathrm{g} / \mathrm{ml}$ of brefeldin A for a further 3 hours. Cells were stained with mAbs specific for human surface markers CD3 and CD8 for 30 minutes. As human CD4 cannot be reliably detected following treatment with PMA, $\mathrm{CD} 4^{+} \mathrm{T}$ cells were represented by $\mathrm{CD} 3^{+} \mathrm{CD} 8{ }^{-}$cells, the vast majority of this population is made up of $\mathrm{CD} 4^{+} \mathrm{T}$ cells, however it will also contain minor populations of innate lymphocytes. Cells were fixed and permeabilised, then stained with mAbs specific for the cytokines IFN- $\gamma$, TNF- $\alpha$ and IL-10 (BD Biosciences, Oxford, UK) and IL-17 (eBioscience, Hatfield, UK). Gating strategy for intracellular cytokines is outlined in supplemental Figure 1B. Cells were acquired using a CyAn ADP flow cytometer (Beckman Coulter) and analysed with FlowJo software (TreeStar Inc.). 


\section{Quantification of cytokine levels in serum, omentum and liver}

The V-PLEX ${ }^{\mathrm{TM}}$ human cytokine plate (Meso Scale Discovery) was used to detect the levels of IL-1 $\beta$, IL-6, IL-12, GM-CSF, IL-4, IL-2, IL-7 and IL-15 in the serum, ACM and LCM of OAC patients according to the manufacturer's instructions and read using a MesoScale Diagnostics Sector S600.

\section{Statistical analyses}

Statistical analysis was carried out using Prism GraphPad Version 5.0. Differences between groups were assessed using two-tailed paired or unpaired t tests where appropriate. $\mathrm{p}$ values of $<0.05$ were considered to be significant. 


\section{Results}

The omentum and liver of OAC patients contain significant proportions of activated effector memory T cells.

Peripheral blood mononuclear cells (PBMC), stromal vascular fraction (SVF) of omentum and intrahepatic immune cells from 11 OAC patients were fluorescently labelled with antibodies against CD3, CD4, CD8, CD45RA, CD27, CD62L, CD69 for subsequent flow cytometric analysis. Percentages of naïve $\left(\mathrm{CD} 45 \mathrm{RA}^{+} \mathrm{CD} 27^{+}\right) \mathrm{CD}^{+} \mathrm{T}$ cells (Blood $42.4 \%$; Omentum 10.9\%; Liver $8.7 \%$ ) were significantly reduced in both the omentum and liver compared with blood, while there were no significant differences observed in the CD4 ${ }^{+} \mathrm{T}$ cell population (Figure 1a). Significantly higher percentages of effector memory (CD45RA ${ }^{-}$ $\left.\mathrm{CD}^{-}\right)^{-} \mathrm{CD}^{+}\left(\right.$Blood 23.9\%; Omentum 56.6\%; Liver 51.1\%) and $\mathrm{CD}^{+}($Blood 8.3\%; Omentum 37.6\%; Liver 34.7\%) T cells were observed in the omentum and/or liver of OAC patients compared to blood (Figure 1a).

There were significantly lower percentages of $\mathrm{CD}_{2} \mathrm{~L}^{+} \mathrm{CD}^{+}$(Blood 81.7\%; Omentum 19.2\%; Liver 13.3\%) and CD62L ${ }^{+} \mathrm{CD}^{+}($Blood 49.3\%; Omentum 19.7\%; Liver 15.4\%) $\mathrm{T}$ cells, while significantly higher percentages of $\mathrm{CD} 9^{+} \mathrm{CD}^{+}$(Blood 4.8\%; Omentum 36.9\%; Liver 42.9\%) and $\mathrm{CD}^{+}$(Blood 4.9\%; Omentum 31.9\%; Liver 52.8\%) T cells were detected in both the omentum and liver of our OAC study cohort, compared to blood (Figure 1b). Interestingly, no statistically significant differences were observed in the frequencies of effector memory, naive or $\mathrm{CD} 69^{+} \mathrm{T}$ cells between the omentum and liver of the OAC cohort thus highlighting the striking similarities of $\mathrm{T}$ cell repertoires in these tissues, compared to the circulation (Figure 1).

The omentum and liver of OAC patients contain significant proportions of inflammatory $\mathrm{CD4}^{+}$and $\mathrm{CDS}^{+} \mathrm{T}$ cells. 
PBMC, SVF and intrahepatic immune cells from 15 OAC patients were fluorescently labelled with antibodies against CD3, CD8, IFN- $\gamma$, TNF- $\alpha$, IL-17 and IL-10 for subsequent flow cytometric analysis.

The percentages of $\mathrm{CD}^{+}\left(\mathrm{CD}^{+} \mathrm{CD}^{-}\right) \mathrm{IFN}-\gamma^{+}(\mathrm{Blood} 3.1 \%$; Omentum 30.6\%; Liver 21.2\%), TNF- $\alpha^{+}\left(\right.$Blood 6.3\%; Omentum 25.2\%; Liver 28.6\%), IL-17 ${ }^{+}($Blood 0.5\%; Omentum 3.7\%; Liver 5.1\%) and $\mathrm{CD}^{+} \mathrm{IFN}-\gamma^{+}\left(\right.$Blood 12.7\%; Omentum 39.1\%; Liver 35.5\%), CD8 ${ }^{+} \mathrm{TNF}-\alpha^{+}$ (Blood 8.1\%; Omentum 45.8\%; Liver 29.4\%) and $\mathrm{CD}^{+} \mathrm{IL}_{-1} 7^{+}($Blood 0.9\%; Omentum 3.7\%; Liver $3.8 \%$ ) $\mathrm{T}$ cells were significantly elevated in both the omentum and liver of OAC patients, compared to blood, but frequencies of $\mathrm{IL}-10$-producing $\mathrm{T}$ cells were not significantly different (Figure 2). Statistical analysis of cytokine-producing $\mathrm{T}$ cell subsets between the omentum and liver revealed no significant differences thus further demonstrating the marked concordance between these tissues in inflammatory profile (Figure 2).

\section{High levels of secreted inflammatory cytokines from both OAC omentum and liver}

Having profiled cytokine expression by $\mathrm{T}$ cells in the blood, omentum and liver, we then quantified secreted inflammatory factors from the serum, adipose and liver conditioned media (ACM and LCM respectively) of 14 OAC patients by multiplex ELISA to determine the inflammatory profile of the multi-cellular tissue. The levels of secreted IL-1 $\beta$, IL-12, GMCSF, IL-6, IL-2, IL-4 and IL-15 were significantly higher in both ACM and LCM compared to serum confirming that the liver is very comparable to the omentum in terms of secreted inflammatory cytokines with the exception of IL-15 levels which were significantly higher in the ACM of OAC patients, compared to LCM (Figure 3). 


\section{Discussion}

Obesity is associated with an imbalance of inflammatory factors and immune cell infiltrates in the omentum and liver, which not only may be relevant to cancer risk, but also liver inflammation in the form of non-alcoholic steatohepatitis (NASH) and fatty liver disease (NAFLD) [17]. Activated and inflammatory Th1 cells, natural killer (NK) cells and NKT cells are present in large numbers in normal healthy liver, and the healthy gut has been identified as a site of "controlled inflammation", in which lymphocytes are functionally and phenotypically distinct to those in the circulation [18]. However, alterations in $\mathrm{CD}^{+} \mathrm{T}$ cells and NKT cells have been reported in non-alcoholic steatohepatitis and cancer in obese murine models $[19,20,21,22,23]$. In human cancer patients, the prevalence of such immune subsets in the VAT and liver has the potential to disrupt tumour surveillance as well as promoting tumourigenic inflammation. Previously, we have shown in OAC patients that activated and pro-inflammatory $\mathrm{T}$ cells and pro-inflammatory cytokines are enriched in the omentum, the primary depot of VAT [8]. Furthermore, we have demonstrated that $\mathrm{T}$ cell enrichments in omentum is most likely due to enhanced $\mathrm{T}$ cell recruitment to this tissue and that the MIP-1 $\alpha$ chemokine pathway, among others, guides T cell migration to both omentum and liver [14]. Here, we investigated whether the enhanced T cell chemotaxis to OAC liver that was previously described, results in an abundance of pro-inflammatory $\mathrm{T}$ cells in this tissue, in parallel to what is observed in the omentum $[8,14]$. We expanded our studies to elucidate the frequencies of TNF- $\alpha$, IL-17 and IL-10 producing T cells in the omentum and liver. The key finding is the concordance between omentum and liver in this cancer cohort, with both Th1 and Th17 cells present in abundance and a reduced proportion of IL-10 ${ }^{+} \mathrm{T}$ cells. There was also a striking concordance in the presence of activated and effector memory $\mathrm{T}$ cell populations at the two tissue sites. Together with our previous findings, these data suggest that similar chemokine gradients are recruiting activated and inflammatory $\mathrm{T}$ cells to 
both the omentum and liver, which in turn may contribute to local and systemic inflammation $[8,14]$.

Of the cytokines assessed in this study many are already known contributors to obesity-associated inflammation, including GM-CSF, IL-1 $\beta$, IL-6 and IL-12 [7, 24, 25, 26, 27]. Furthermore, IL-6 has been implicated in the development of NAFLD in human obesity, while IL-1 $\beta$ is involved in progression from steatosis to steatohepatitis [28, 29]. Interestingly, levels of IL-2 and IL-4 were detected in our patient cohort but could not be detected in a previous study examining adipose tissue resident $\mathrm{CD}^{+}$and $\mathrm{CD} 8^{+} \mathrm{T}$ cells, this may be due to enhanced trafficking of non-resident T cells producing these cytokines in the omentum [30]. Previous studies have implicated IL-15 in decreased lipid deposition and have reported that obese individuals have reduced serum levels compared to normal weight adults [31]. However, to our knowledge, the present study is the first to report abundant levels of this T and NK cell stimulating cytokine in human omentum. While the abundance of IL-1 $\beta$, IL-6, IL-12 and IL-2 was mirrored in matched omentum and liver samples, both of these tissues contained equally low levels of IL-7.

There is important therapeutic relevance for these novel findings as we have shown for the first time that Th1 and Th17 cells are likely contributors to pathological inflammation in the omentum and liver of patients with obesity-associated cancer, and that naive $\mathrm{T}$ cells and IL-10 producing T cells subsets are not prevalent at these sites. Importantly, these data suggest that strategies such as chemokine receptor antagonism targeting the recruitment of such inflammatory cells to the omentum of obese patients will also reduce their prevalence in liver and have direct consequences for NAFLD.

In conclusion, this study has for the first time compared the inflammatory profile of the omentum and liver, utilising a clinically relevant model of obesity and inflammationassociated cancer, oesophageal adenocarcinoma. Our novel findings demonstrate that these 
proximal tissues are enriched in both inflammatory cells and secreted factors that are conducive to obesity-associated inflammation and numerous associated pathologies, including cancer. This suggests that therapeutic strategies should target inflammation at both omental and hepatic sites in obese patients.

Informed consent: Informed consent was obtained from all individual participants included in the study.

Ethical approval: "All procedures performed in studies involving human participants were in accordance with the ethical standards of the institutional and/or national research committee and with the 1964 Helsinki declaration and its later amendments or comparable ethical standards."

Funding: This study was funded by the Health Research Board of Ireland Health Research Award HRA_POR/2011/91.

Conflict of Interest: The authors declare that they have no conflict of interest. 


\section{References}

1. Roberts, D.L., Dive C., and Renehan A.G. Biological mechanisms linking obesity and cancer risk: new perspectives. Annu. Rev. Med. 2010; 61: 301-316.

2. Scheen, A.J. and Luyckx F.H.. Obesity and liver disease. Best Pract. Res. Clin. Endocrinol. Metab. 2002; 16(4): 703-716.

3. Goran, M.I., Ball, G.D.C. and Cruz M.L. Obesity and risk of type 2 diabetes and cardiovascular disease in children and adolescents. J. Clin. Endocrinol. Metab. 2003; 88(4): $1417-1427$.

4. www.who.int

5. www.cancer.gov

6. Calle, E.E., Rodriguez, C. Walker-Thurmond K., et al. Overweight, obesity, and mortality from cancer in a prospectively studied cohort of U.S. adults. N. Engl. J. Med. 2003; 348(17): $1625-1638$.

7. Lysaght, J., van der Stok, E.P., Allott, E.H., et al. Pro-inflammatory and tumour proliferative properties of excess visceral adipose tissue. Cancer Lett. 2011; 312: 62-72.

8. Lysaght, J., Allott, E.H., Donohoe, C.L., et al. T lymphocyte activation in visceral adipose tissue of patients with oesophageal adenocarcinoma. British Journal of Surgery. 2011; 98: 964-974.

9. Lynch L.A., O'Connell J.M., Kwasnik A.K., et al. Are natural killer cells protecting the metabolically healthy obese patient? Obesity (Silver Spring). 2009; 17(3):601-5.

10. Lynch L, O'Shea D, Winter DC, et al. Invariant NKT cells and CD1d(+) cells amass in human omentum and are depleted in patients with cancer and obesity. Eur J Immunol. 2009; 39(7):1893-901. 
11. Lynch L, Nowak M, Varghese B, et al. Adipose tissue invariant NKT cells protect against diet-induced obesity and metabolic disorder through regulatory cytokine production. Immunity. 2012; 37(3):574-87.

12. Deiuliis J, Shah Z, Shah N, et al. Visceral adipose inflammation in obesity is associated with critical alterations in tregulatory cell numbers. PLoS One. 2011; 26;6(1):e16376.

13. Nishimura, S., Manabe I., Nagasaki M., et al. CD8+ effector T cells contribute to macrophage recruitment and adipose tissue inflammation in obesity. Nat Med 2009; 15(8): 914-20.

14. Conroy M.J., Galvin K.C., Kavanagh M.E., Mongan A.M., Doyle S.L., Gilmartin N., Reynolds J.V. and J Lysaght. CCR1 antagonism attenuates T cell trafficking to omentum and liver in obesity-associated cancer. Immunol Cell Biol 2015; PMID: 27046081.

15. Doyle, S.L., Bennett, A.M., Donohoe, C.L., et al. Establishing computed tomographydefined visceral fat area thresholds for use in obesity-related cancer research. Nutr Res. 2013; 33(3):171-179.

16. Curry M.P., Norris, S., Golden-Mason, L., et al. Isolation of lymphocytes from normal adult human liver suitable for phenotypic and functional characterisation. JIM 2000; 242: 2131.

17. Ebbert J.O. and Jensen M.D. Fat Depots, Free Fatty Acids, and Dyslipidemia. Nutrients. $2013 ; 5 ; 498-508$.

18. Shanahan F. A gut reaction: lymphoepithelial communication in the intestine. Science.1997;275(5308):1897-8.

19. Xu CF, Yu CH, Li YM, et al. Association of the frequency of peripheral natural killer T cells with nonalcoholic fatty liver disease. World J Gastroenterol. 2007; 13(33):4504-8. 
20. Guebre-Xabier M, Yang S, Lin HZ, et al. Altered hepatic lymphocyte subpopulations in obesity-related murine fatty livers: potential mechanism for sensitization to liver damage. Hepatology. 2000;31:633-640

21 Kenna T, Golden-Mason L, Porcelli SA, et al. NKT cells from normal and tumour-bearing human livers are phenotypically and functionally distinct from murine NKT cells. J Immunol. $2003 ; 171(4): 1775-9$.

22. Wolf MJ, Adili A, Piotrowitz K, et al. Metabolic activation of intrahepatic CD8+ T cells and NKT cells causes nonalcoholic steatohepatitis and liver cancer via cross-talk with hepatocytes. Cancer Cell. 2014; 26(4):549-64. 25.

23. Doherty DG, Norris S, Madrigal-Estebas L, et al. The human liver contains multiple populations of $\mathrm{NK}$ cells, $\mathrm{T}$ cells, and $\mathrm{CD}^{+} \mathrm{CD}^{+} 6^{+}$natural $\mathrm{T}$ cells with distinct cytotoxic activities and Th1, Th2, and Th0 cytokine secretion patterns. J Immunol. 1999;163(4):231421.

24. Kim D.H., Sandoval D., Reed J.A., Matter E.K., Tolod E.G., Woods S.C. ad R.J. Seeley. The role of GMCSF in adipose tissue inflammation Am J Physiol Endicrinol Metab 2008; 295(5); 1038-1046.

25. Gilbert and J. M. Slingerland, "Cytokines, obesity, and cancer: new insights on mechanisms linking obesity to cancer risk and progression.," Annu. Rev. Med., 2013; 45-57.

26. Lutz C.T. and L. S. Quinn, "Sarcopenia, obesity, and natural killer cell immune senescence in aging: altered cytokine levels as a common mechanism.," Aging (Albany. NY)., 2012; 4(8):535-46.

27. Karin M, "NF-kappaB as a critical link between inflammation and cancer.," Cold Spring Harb. Perspect. Biol., 2009; 1(5): 000141. 
28. Wieckowska A, Papouchado BG, Li Z, Lopez R, Zein NN, Feldstein AE. Increased hepatic and circulating interleukin-6 levels in human nonalcoholic steatohepatitis. Am $J$ Gastroenterol. 2008;103:1372-1379.

29. Tilg H., Moschen A.R. IL-1 cytokine family members and NAFLD: neglected in metabolic liver inflammation. J. Hepatol. 2011; 55(5): 960-962.

30. Yang H., Youm Y.H., Vandanmagsar B., Ravussin A., Gimble J.M., Greenway F., Stephens J.M., Mynatt R.L., Dixit V.D. Obesity increases the production of proinflammatory mediators from adipose tissue $\mathrm{T}$ cells and compromises TCR repertoire diversity: implications for systemic inflammation and insulin resistance. J Immunol. 2010 185(3):18361845.

31. Barra, N. G., Reid, S., MacKenzie, R., Werstuck, G., Trigatti, B. L., Richards, C., Holloway, A. C. and Ashkar, A. A. (2010), Interleukin-15 Contributes to the Regulation of Murine Adipose Tissue and Human Adipocytes. Obesity, 18: 1601-1607. 


\section{Figure Legends}

Figure 1: The omentum and liver of OAC patients are enriched with activated, effector memory T cells. PBMC, stromal vascular fraction (SVF) and intrahepatic immune cells isolated from the blood and omentum of $11 \mathrm{OAC}$ patients and the liver of 8 OAC patients were fluorescently labelled with antibodies against CD3, CD4, CD8, CD45RA, CD27, CD62L and CD69. a: Bar charts showing that the mean percentages of CD45RA ${ }^{+} \mathrm{CD} 27^{+}$ $\mathrm{CD}^{+} \mathrm{T}$ cells (naïve, top right) are lower while $\mathrm{CD}^{2} 5 \mathrm{RA}^{-} \mathrm{CD} 27^{-}$(effector memory, bottom) $\mathrm{CD}^{+}$(left) and $\mathrm{CD}^{+}$(right) $\mathrm{T}$ cells are higher in the omentum and liver, compared to blood. b: Bar charts showing mean percentages of $\mathrm{CD} 2 \mathrm{~L}^{+}$(naïve, top) $\mathrm{CD}^{+}$(left) and $\mathrm{CD} 8^{+}$(right) $\mathrm{T}$ cells are lower while $\mathrm{CD}^{+} 9^{+}$(activated, bottom) $\mathrm{CD}^{+}$(left) and $\mathrm{CD}^{+}$(right) $\mathrm{T}$ cells are expanded in omentum and liver, compared to the blood of OAC patients. ${ }^{*} \mathrm{p}<0.05$, ${ }^{*} \mathrm{p}<<0.01$, $* * * \mathrm{p}<0.001$

Figure 2: The omentum and liver of OAC patients are enriched with pro-inflammatory T cells. PBMC, SVF and intrahepatic immune cells isolated from the blood of 15 and omentum and liver of $14 \mathrm{OAC}$ patients were fluorescently labelled with antibodies against CD3, CD8, IFN- $\gamma$, TNF- $\alpha$, IL-17 and IL-10 and analyzed by flow cytometry. Bar charts showing mean percentages of IFN- $\gamma^{+}, \mathrm{TNF}^{-} \alpha^{+}$and $\mathrm{IL}-17^{+} \mathrm{CD} 8^{-} \mathrm{CD} 3^{+}(\mathrm{left})$ and $\mathrm{CD} 8^{+} \mathrm{CD} 3^{+}$ (right) $\mathrm{T}$ cells are significantly higher in omentum and liver, compared to the blood of OAC patients while significant differences are not observed in the $\mathrm{IL}-10^{+}$fractions. ${ }^{*} \mathrm{p}<0.05$, $* * \mathrm{p}<0.01, * * * \mathrm{p}<0.001$.

Figure 3: The omentum and liver of OAC patients are enriched with secreted inflammatory factors. The secreted levels of IL-6, IL-1 $\beta$, GMCSF, IL-12, IL-2, IL-4, IL-7 and IL-15 were quantified in the serum, adipose conditioned media (ACM) and liver conditioned media (LCM) of 14 EAC patients using MSD ELISA. Bar charts showing the mean concentrations of IL-6, IL-1 $\beta$, GMCSF, IL-12, IL-2, IL-4 and IL-15 are significantly 
higher in the ACM and LCM of 14 EAC patients while concentrations of IL-7 are lower, compared to serum. ${ }^{*} \mathrm{p}<0.05, * * \mathrm{p}<0.01, * * * \mathrm{p}<0.001$.

Supplemental Data Figure 1: Representative dotplots showing the gating strategy for surface marker expression and intracellular cytokine expression by T lymphocytes.

a (Left-Right): For surface marker quantification, forward scatter and side scatter were first used to gate on lymphocytes, followed by gating of $\mathrm{CD}^{+} \mathrm{CD} 4^{-}$lymphocytes and $\mathrm{CD}^{-} \mathrm{CD} 4^{+}$ lymphocytes. CD62L was then quantified as a percentage of either $\mathrm{CD}^{+} \mathrm{CD} 4^{-}$lymphocytes or $\mathrm{CD}^{-} \mathrm{CD}^{+}{ }^{+}$lymphocytes. b (Left-Right): For intracellular cytokine quantification, forward scatter and side scatter were first used to gate on lymphocyte gate, followed by gating of $\mathrm{CD}^{+} \mathrm{CD}^{+}$lymphocytes and $\mathrm{CD} 8^{-} \mathrm{CD}^{+}$lymphocytes. TNF- $\alpha^{+}$cells were then quantified as a percentage of $\mathrm{CD}^{+} \mathrm{CD}^{+}$lymphocytes or $\mathrm{CD} 8^{-} \mathrm{CD} 3^{+}$lymphocytes. 
a
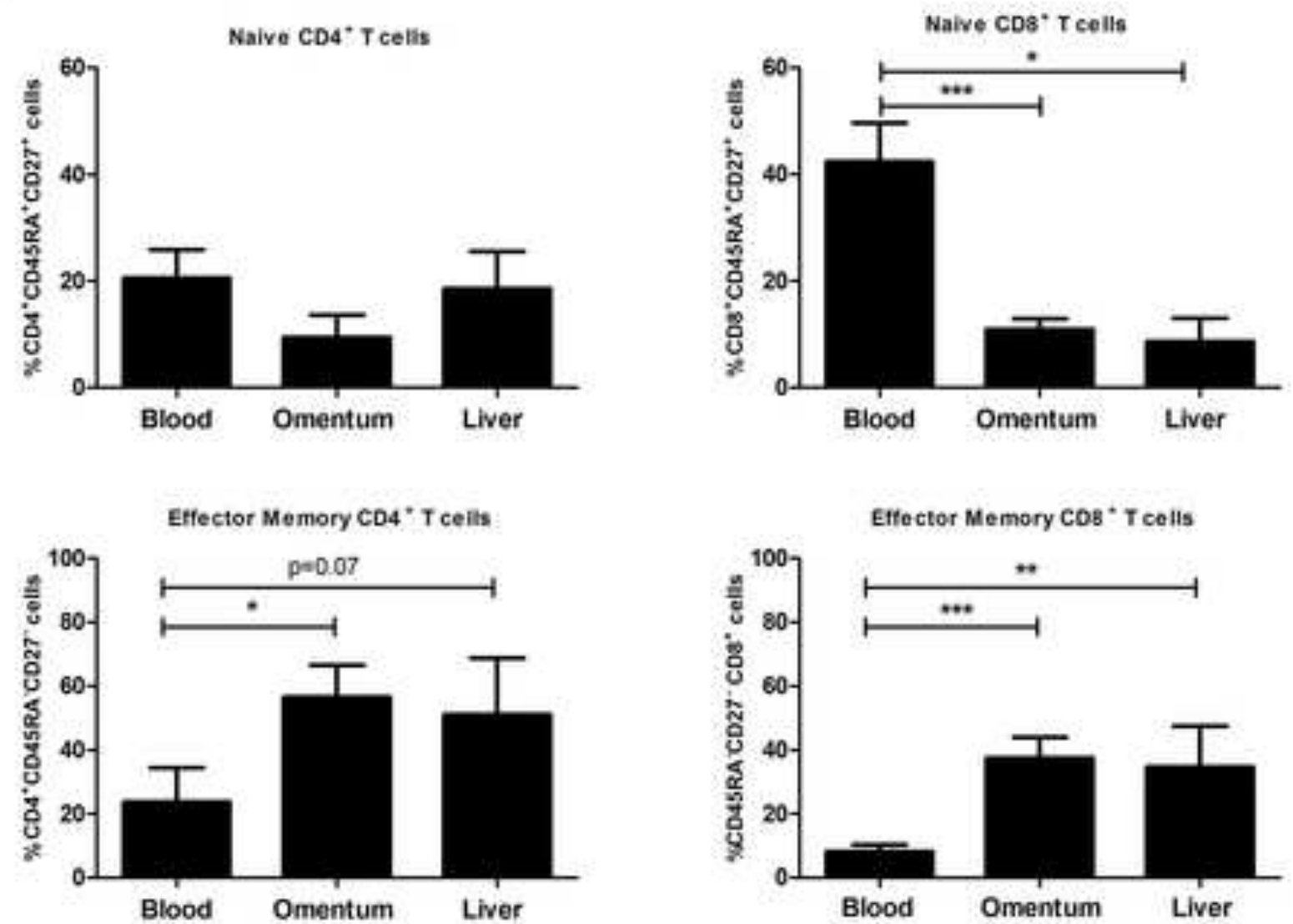

b
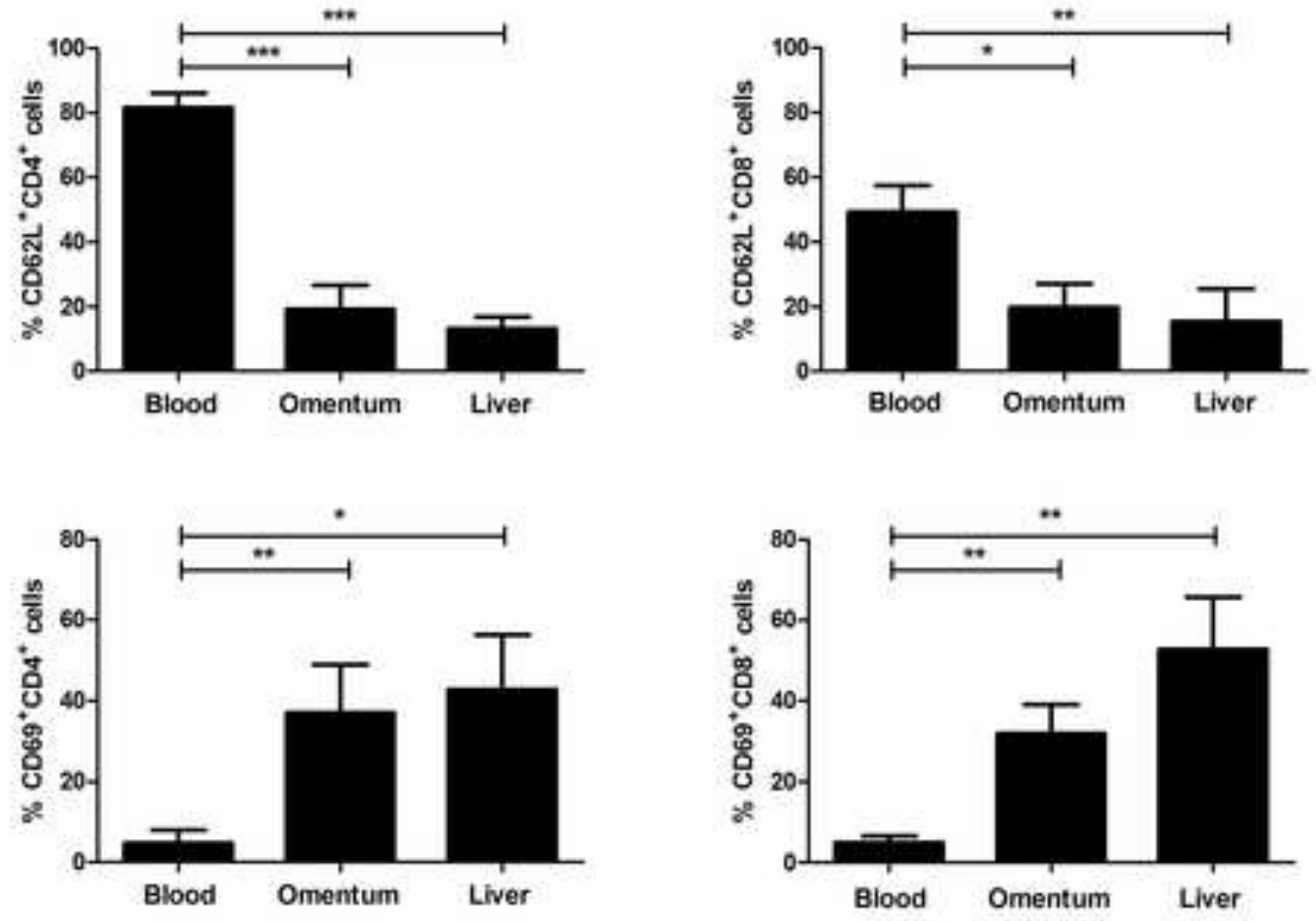

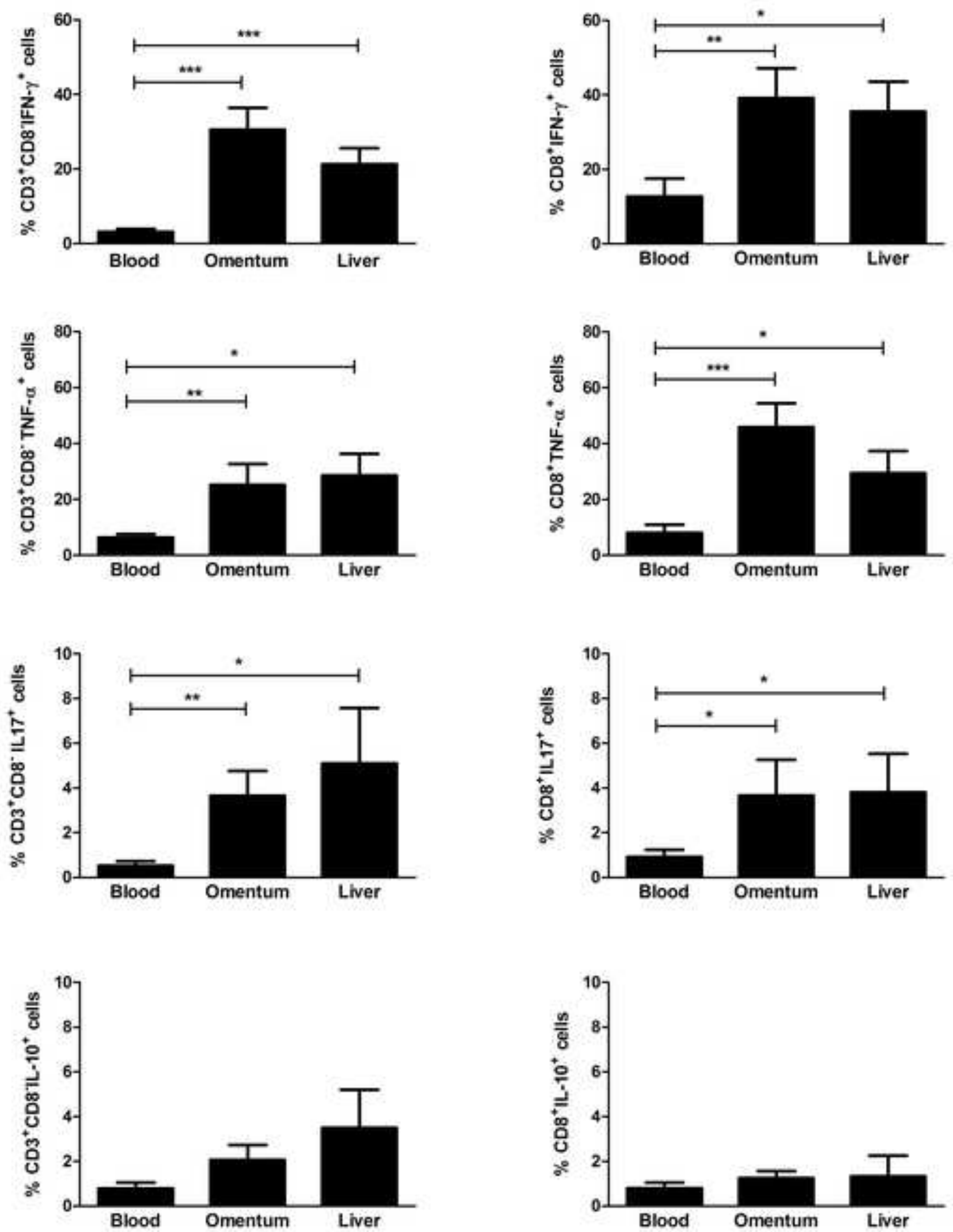

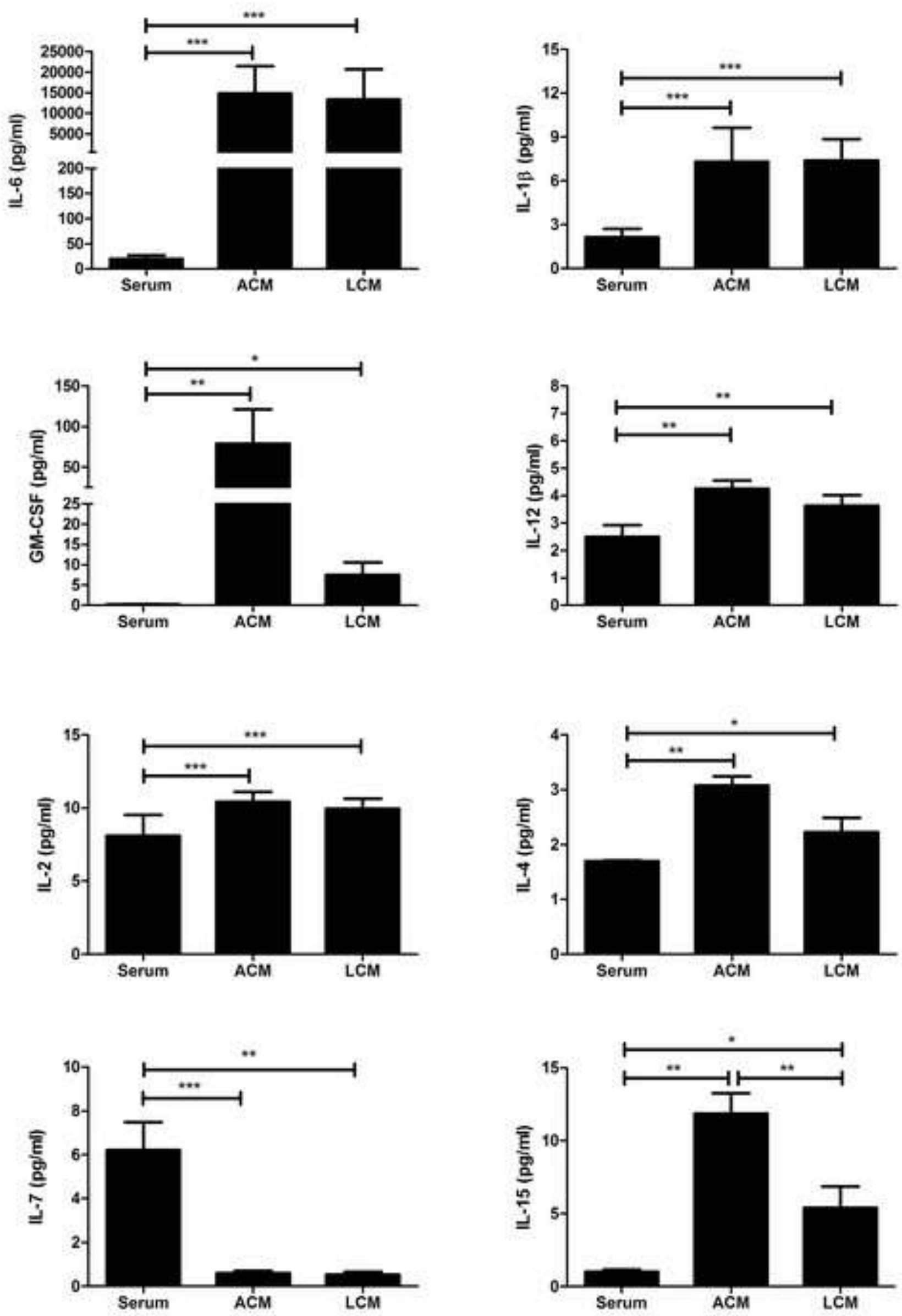


\section{SUPPLEMENTAL Figure 1}

a
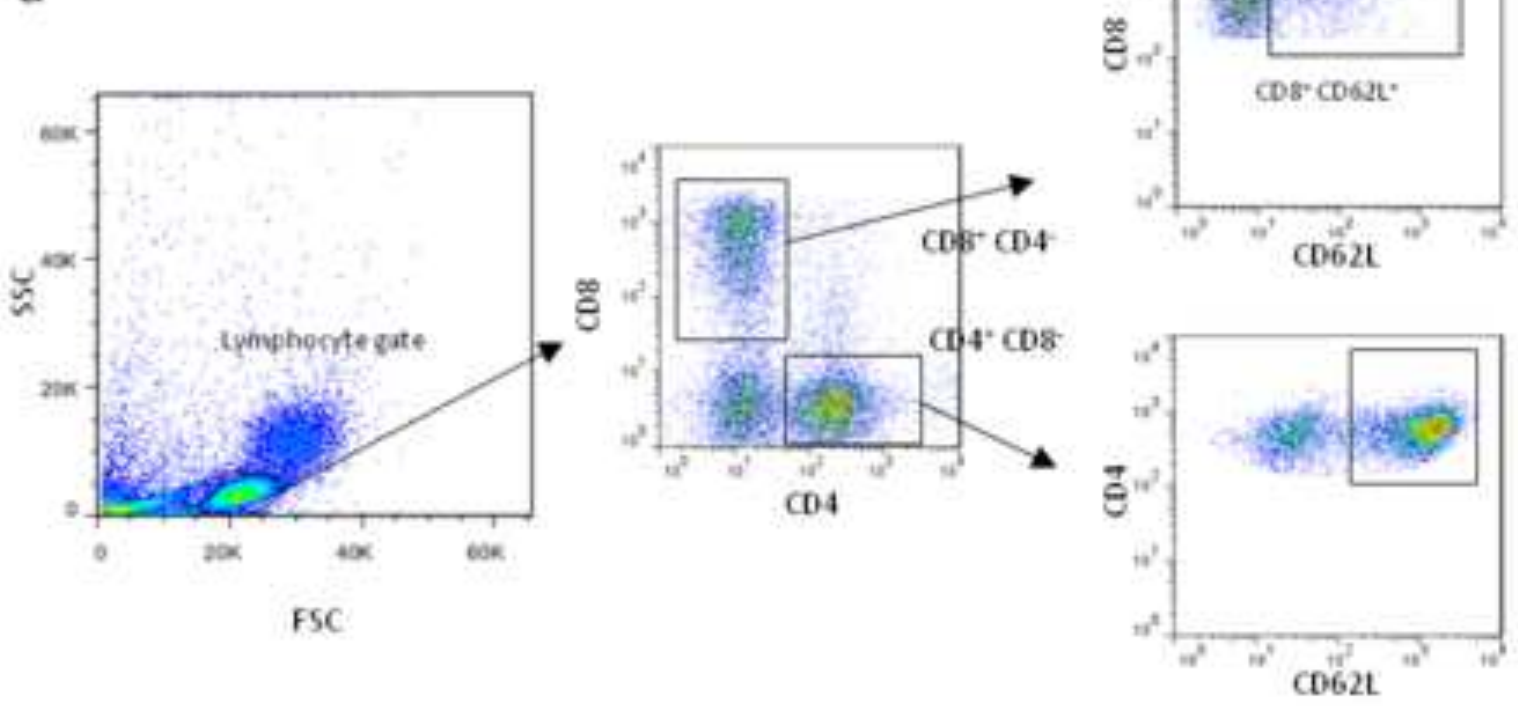

b
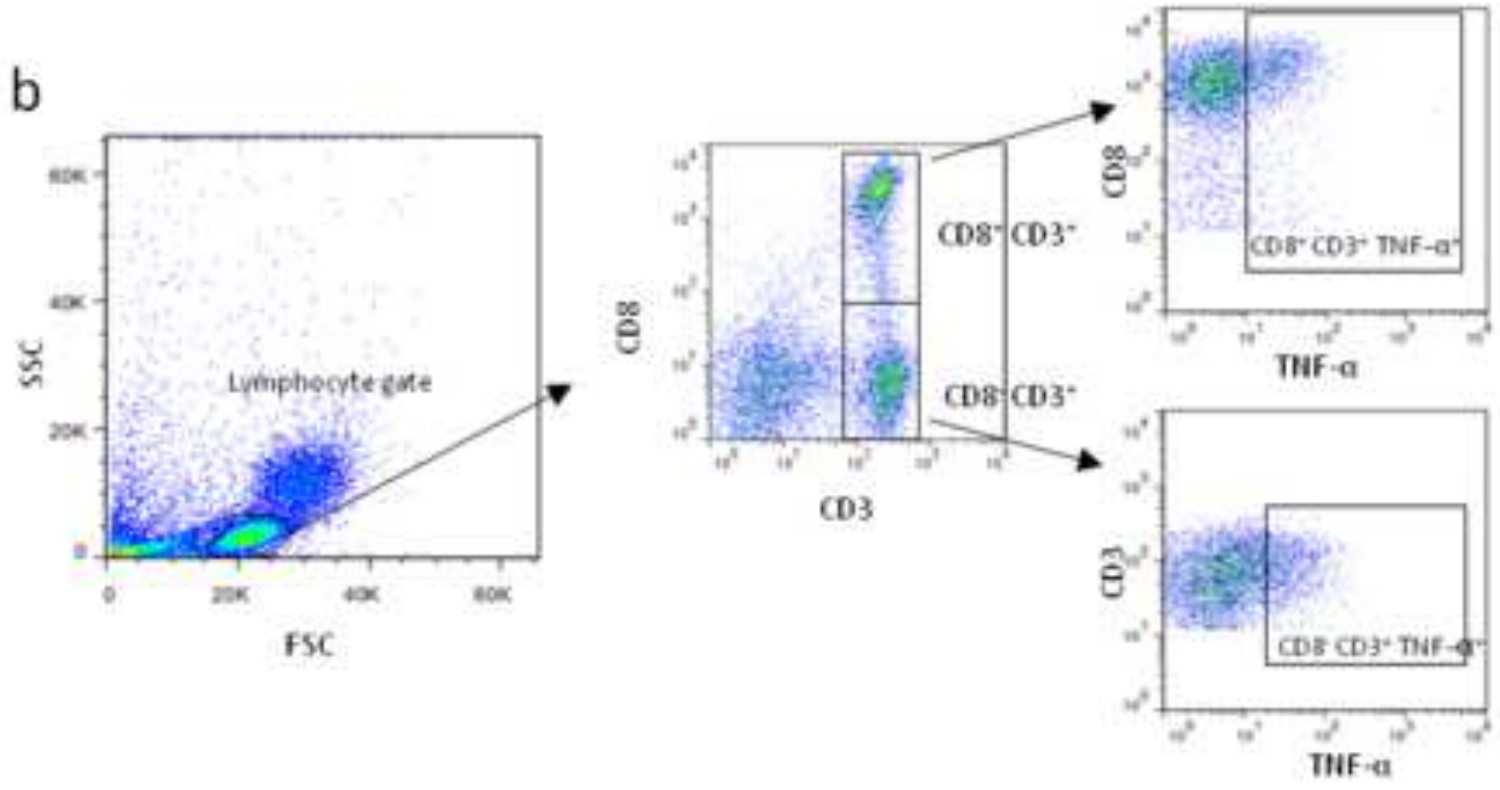